\title{
Canada (Attorney-General) v. Ward: A Review Essay
}

\author{
AUDREY MACKLIN*
}

\begin{abstract}
The Supreme Court of Canada's recent judgment in Canada (Attomgy-General) u Wand considers various aspects of the international Conventzon refugee definition. The claimant fled Northern Ireland to escape retaliation by the Irish National Liberation Army (INLA) for his effective defection from that organization. The Ward judgment reinforces the position that State complicity is not a pre-requisite to a determination of persecution by finding that the inability of the Irish and UK police to protect the claimant from INLA reprisal could suffice for purposes of establishing a well-founded fear of persecution. Second, the decision adopts a relatively expansive interpretation of the term 'particular social group' by linking the designation to concepts of anti-discrimination in Canadian and international law. In obiter, the Court declares that gender and sexual orientation are permissible bases for social group ascription. On the facts of this case, however, the claimant failed to establish that he was persecuted because of his membership in a particular social group. On the other hand, the Court was sympathetic to the alternative of political opinion. In its analysis of this ground, the Court confirms that a claimant may be persecuted for reasons of political opinion even where the opinion is inferred from conduct or wrongly imputed to the claimant. In the present case, Ward's political opposition to the tactics of the INLA could be inferred from his conduct in releasing hostages he was ordered to guard. Finally, the decision clarifies the scope of the 'dual nationality' exclusion that may be used to bar a refugee claim. In this case, the Court found that the Federal Court of Appeal had erred by failing to consider the fact that Ward was a citizen of the United Kingdom as well as Ireland, but cautioned that it might still be possible to conclude that the United Kingdom would be unable or unwilling to protect him from INLA retaliation.
\end{abstract}

\section{Introduction}

On 30 June 1993, the Supreme Court of Canada released its long awaited decision in Attomey-General of Canada v. Ward. ${ }^{\prime}$ The judgment touches on numerous aspects of refugee law, including the definition of persecution,

- Assistant Professor, Dalhousie Law School, Halifax, Canada. The author thanks Lisa Gilad and James Hathaway for comments on an earlier draft. Since writing this article, the author has been appointed a Member of the Immigration and Refugee Board (IRB) of Canada. The views expressed in this article are the personal views of the author and are not necessarily shared by the IRB.

1 [1993] 2 SCR 689. All citations hereafter are to page numbers of the judgment.

International Journal of Refugee Law Vol 6 No. 3 
the scope of the 'social group' category and the 'double nationality' rule. The judgment contains a most comprehensive analysis of the Convention refugee definition; as such, its precedential value ought to transcend Canadian borders and attract the attention of all States Party to the 1951 Convention and 1967 Protocol Relating to the Status of Refugees. ${ }^{2}$

\subsection{The Facts}

Mr. Ward had been a member of the Irish National Liberation Army (INLA). The Court described the INLA as 'a ruthless para-military organization more violent than the Irish Republican Army', but sharing the same aspiration of liberating Northern Ireland from British rule. Ward had been assigned to guard hostages held by the INLA in order to encourage one of their arrested members not to turn informer, but he allowed them to escape when he learned of their impending execution. When Ward's role in the escape was discovered by the INLA, Ward himself was detained, tortured and sentenced to death. Though he eventually escaped and sought protection from the Irish police, he was in turn charged for his role in the initial hostage-taking. He pleaded guilty to forcible confinement and was sentenced to three years in prison. At the expiration of his prison term, he obtained the assistance of a prison chaplain in arranging his flight to Canada, where he eventually claimed refugee status. His claim was successful before the Immigration Appeal Board, but was overturned and sent back for rehearing by the Federal Court of Appeal. Mr. Ward appealed that decision to the Supreme Court of Canada. The Supreme Court of Canada allowed the appeal, while remitting the case back to the Immigration and Refugee Board for an evaluation on the issue of dual nationality. ${ }^{3}$

\subsection{Refugee Definition}

Canadian law incorporates the international Convention refugee definition into its domestic immigration legislation, the Canadian Immigration Act. Section 2 states that a 'Convention refugee' means any person who

(a) by reasons of a well-founded fear of persecution for reasons of race, religion, nationality, membership in a particular social group or political opinion,

(i) is outside the country of the person's nationality, and is unable or, by reason of that fear, is unwilling to avail himself [sic] of the protection of that country, or

(ii) not having a country of nationality, is outside the country of the person's

${ }^{2}$ United Nations Convention Relating to the Status of Refugees, opened for signature 28 July $1951 \cdot 189$ UNTS 137 (hereafter 'Convention'); Prolocol Relaung to the Status of Refugees, opened for signature $31 \mathrm{Jan}$ 1967: 606 UNTS 267.

3 The organization of the immigration and refugee bureaucracy has changed since 1985, today, Ward would appear before the Conventon Refuget Determination Dursion of the Immigration and Refuget Board rather than the Immigration Appeal Board. 
former habitual residence and is unable or, by reason of that fear, is unwilling to return to that country, and

(b) has not ceased to a Convention refugee by virtue of subsection (2) ...

\section{Elements in the Judicial Reasoning}

\subsection{Persecution}

The judgment cites with approval a definition of persecution that encompasses 'sustained or systematic violation of basic human rights'. Perhaps because torture and killing are paradigmatic examples of 'persecution', the judgment does not enter into extensive analysis of what constitute 'basic human rights' or what counts as 'systematic' or 'sustained' denial of those rights.

\subsection{State Complicity}

Ward did not apprehend persecution at the hands of the Irish government. Rather, he feared torture and possible death by the INLA from which the Irish government could not protect him. This raised the following issue for the Court to consider: 'Is the element of State complicity, either through direct persecution, collusion with the persecuting agents, or wilful blindness to the actions of the persecuting agents, a requisite element in establishing a refugee claimant's 'unwillingness' to avail him- or herself of the protection of his or her country of nationality?"5

The short answer is no. Writing for the Court, Mr. Justice La Forest declares that 'state complicity in persecution is not a pre-requisite to a valid refugee claim'. ${ }^{6}$ Put another way, serious violations of human rights by non-state actors can ground a finding of persecution under the refugee definition if the State cannot or will not protect nationals from such mistreatment. In coming to its conclusion, the Court examined the drafting history of the Convention, the UNHCR Handbook on Procedures and Criteria for Determining Refugee Status,' Canadian and United States refugee cases, and scholarly commentary. With the exception of the travaux préparatoires, ${ }^{8}$ which La Forest J. found inconclusive, the remainder of the sources supported the proposition that State inability to protect can trigger a finding of persecution. ${ }^{9}$

Despite its extensive citation of authority, the judgment does not actually

$434 ;$ also at 733

5708 .

6713.

' UNHCR, Handbook on Procedures and Critena for Determinng Refugee Slatus, Geneva, 1979. (Hereafter, 'Handbook').

B Alex Takkenberg and Christopher Tahbaz, The Collected Travaux PrAparatoires of the 1951 Genesa Convention relating to the Status of Refugees. Amsterdam: Dutch Refugee Council, 1990.

${ }^{9}$ 713-17. 
articulate the rationale behind its conclusion. Earlier in his judgment, La Forest $\mathrm{J}$. makes the following observation about the foundation of refugee law:

International refugee law was formulated to serve as a back-...up to protection one expects from the state of which an individual is a national. It was meant to come in to play only in situations when that protection is unavailable, and then only in certain situations. ${ }^{10}$

One might gather from this comment that the Court proceeds from a tacit understanding that the State owes its nationals not only a duty to refrain from abusing its power by violating their fundamental rights, but also a duty to protect citizens from attempts by others to do likewise. As La Forest J. remarks elsewhere, '[s] ecurity of nationals is, after all, the essence of sovereignty'. "The logical implication is that if a State falters in either regard, it has failed to fulfil its most basic obligations toward its nationals, who are hence entitled to seek refuge elsewhere.

\subsection{Unable/Unwilling}

In order to meet the refugee definition, Ward had to prove that he was unable or unwilling to return to his country of nationality because of his well-founded fear of persecution. La Forest J. defines 'unable' and 'unwilling' as follows:

[] $\mathrm{n}$ the case of 'inability', protection is denied to the claimant, whereas when the claimant is 'unwilling', he or she opts not to approach the state by reason of his or her fear on an enumerated basis ${ }^{12}$

In a particularly obscure passage, Urie JA of the Federal Court of Appeal attempted to formulate a test linking Ireland's inability to protect Ward to Ward's inability or unwillingness to avail himself of State protection. ${ }^{13}$ The Supreme Court of Canada judgment clarifies this issue, declaring that,

Whether the claimant is 'unwilling' or 'unable' to avail him- or herself of the protection of a country of nationality, state complicity in the persecution is irrelevant. The distinction between these two branches of the 'Convention refugee' definition resides in the party's precluding resort to state protection: in the case of 'inability', protection is denied to the claimant, whereas when the claimant is 'unwilling', he or she opts not to approach the state by reason of his

10709 .

11725 .

12720.

13 Attomey General a Ward, [1990] 2 FC 667 at 680, per Une JA, quoted in Ward, at 705-6. For comment on the decision of the Federal Court of Appeal decision, see Bagambiire, D.B.N., 'Terrorism and Convention Refugee Status in Canadian Immigration Law. The Social Group Category according to Wand u Canada,' 5 THRL 183 (1992). 
or her fear on an enumerated basis. In either case, the state's involvement in the persecution is not a necessary consideration..$^{14}$

\subsection{Test For Determining Fear of Persecution}

Mr. Justice La Forest notes that paragraph 65 of the UNHCR Handbook injects State failure to protect into the definition of persecution, such that 'acts by private citizens, when combined with State inability to protect, constitute 'persecution". ${ }^{15}$ Though the Ward decision is not free from ambiguity on this point, it appears that the Court departs from the view that the definition of persecution must necessarily implicate the State, be it through State action or culpable inaction. Instead, La Forest J. posits that State inability to protect a national from non-state perpetrators of maltreatment is only relevant to the well-foundedness of the claimant's fear of persecution and, by extension, to the reasonableness of the claimant's inability or unwillingness to seek State protection. The role played by the State as perpetrator, accomplice or impotent bystander would not, however, be germane to the issue of whether the conduct feared constitutes persecution in the first place. ${ }^{16}$ Thus, when speaking of the requirement that a fear of persecution be well-founded, La Forest J. comments that '[i]t is at this stage that the State's inability to protect should be considered. . . . if a state is able to protect the claimant, then his or her fear is not, objectively speaking, well-founded. ${ }^{17}$

If a refugee claim is predicated on the inability or unwillingness of the claimant to seek State protection from persecution by third parties, must the claimant first seek State protection in order to prove it illusory? La Forest J. rejects the notion that a claimant must prove that he or she unsuccessfully sought State protection in the past order to justify an unwillingness to avail himself or herself of State protection for purposes of establishing a refugee claim: 'it would seem to defeat the purpose of international protection if a claimant would be required to risk his or her life seeking ineffective protection of a state, merely to demonstrate that ineffectiveness'. ${ }^{18}$ On the other hand, La Forest J. endorses Hathaway's opinion that the failure to seek State protection will defeat a claim where such protection 'might reasonably have been forthcoming. ${ }^{19}$

Once a claimant has established that he or she fears persecution, and that the State cannot provide protection, a decision maker may presume

$14720-1$

15714 .

16722 : 'It is clear that the lynch-pin of the analysis is the state's inability to protect: it is a crucial element in determining whether the claimant's fear is well-founded, and thereby the objective reasonableness of his or her unwillingness to seek the protection of his or her state of nationality.'

17712.

18724 .

19 Ibid. 
that the fear is 'well-founded' for purposes of satisfying the objective component of the refugee definition:

I see nothing wrong with this [presumption], if the Board is satisfied that there is a legitimate fear, and an established inability of the state to assuage those fears through effective protection. The presumption is not a great leap. Having established the existence of a fear and a state's inability to assuage those fears, it is not assuming too much to say that the fear is well-founded. Of course, the persecution must be real the presumption cannot be built on fictional events but the well-foundedness of the fears can be established through the use of such a presumption. ${ }^{20}$

Having purportedly created one presumption in favour of the claimant, La Forest $\mathrm{J}$. hastens to even the procedural score by imposing an onerous evidentiary burden on the claimant in relation to the State's inability to protect. According to La Forest J., absent 'clear and convincing proof' to the contrary, it should be presumed that the state is capable of protecting a claimant ${ }^{22}$. Ward was fortunate (so to speak) in that Irish State authorities conceded their inability to protect him. In cases where such an admission is not forthcoming, 'clear and convincing confirmation of a state's inability to protect must be provided'. Suitable evidence would consist of testimony by 'similarly situated individuals' who were 'let down by the state protection arrangements' or 'the claimant's testimony of past personal incidents in which state protection did not materialize'. Without evidence of this nature 'the claim should fail, as nations should be presumed capable of protecting their citizens'. ${ }^{23}$

\section{Grounds of Persecution}

\subsection{Particular Social Group}

The Ward decision sets out the criteria for establishing whether one is persecuted as a member of a 'particular social group'. Once again, the Court consulted the travaux préparatoires of the Convention, the UNHCR Handbook, Canadian and United States jurisprudence and scholarly authority. A significant influence on the Court was what La Forest J. referred to as principles of anti-discrimination. La Forest J. cites with approval Goodwin-Gill, ${ }^{24}$ who makes the following linkage between the refugee definition and principles of non-discrimination in international law:

\footnotetext{
${ }^{20} 722$.

21 726 ; also at 724 .

${ }^{22}$ 725. La Forest J. tempers his comments a sentence later by conceding that, "the presumption will not operate in a situation of complete breakdown of state apparatus' (for example, Lebanon during the civil war).

${ }^{23} 725$.

24 The Refugee in Intemational Law Oxford: Clarendon Press, 1983
} 
The references to 'race, religion, nationality, membership [in] a particular social group, or political opinion' illustrate briefly the characteristics of individuals and groups which are considered worthy of special protection. These same factors have figured in the development of the fundamental principle of non-discrimination in general international law, and have contributed to the formulation of other fundamental human rights. ${ }^{25}$

La Forest J. also relies on Hathaway's argument that the anti-discrimination influence in refugee law is justified on the basis of those sought to be protected thereby:

The early refugee accords did not articulate this notion of disenfranchisement or breakdown of basic membership rights, since refugees were defined simply by specific national, political and religious categories, including anti-Communist Russians, Turkish Armenians, Jews from Germany, and others. The de facto uniting criterion, however, was the shared marginalization of the groups in their states of origin. . It was the lack of a meaningful stake in the governance of their own society which distinguished them from others, and gave legitimacy to their desire to seek protection abroad. ${ }^{26}$

Finally, Mr. Justice La Forest derives guidance from the equality provision of Canada's domestic constitution, the Canadian Charter of Rights and Freedoms. ${ }^{27}$ Section 15 of the Charter guarantees, inter alia, equal protection and benefit of the law 'without discrimination and, in particular, without discrimination based on race, national or ethnic origin, colour, religion, sex, age or mental or physical disability'. Section 15 is not limited in its application to the enumerated list of grounds, and the phrase 'analogous grounds' has come to describe other categories of discrimination to which section 15 will apply. La Forest J. hints that 'particular social group' may be to the refugee definition what 'analogous grounds' are to the Charter equality provision, namely, 'the distillation of and extrapolation from the common thread running through the enumerated heads'. ${ }^{28}$ In the context of the refugee definition, this can be taken to mean that the categories preceding 'particular social group' (race, religion and nationality) may be understood as specific examples of particular social groups.

Drawing mainly on the jusrisprudence of United States and Canadian lower courts, La Forest J. identifies three possible categories of social group ascription:

(1) groups defined by an innate or unchangeable characteristic;

(2) groups whose members voluntarily associate for reasons so fundamental to their human dignity that they should not be forced to forsake the association;

${ }^{25}$ Quoted at 734.

${ }^{26}$ Quoted at 735.

27 Constitution Att, 1982, RSC 1985, App. II, No 44, Schedule B.

28738. 
(3) groups associated by a former voluntary status, unalterable due to its historical permanence. ${ }^{29}$

The lower courts had characterized Ward as belonging to a social group described as members or former members of the INLA. ${ }^{30}$ The Court rejects both designations, noting that the INLA's reasons for targeting Ward and Ward's fear of retaliation existed 'whether or not Ward renounced his membership in the INLA, as the possibility of revealing organization secrets is present in the case of both present and former members'. ${ }^{31}$ In any event, Ia Forest J. concludes that Ward, qua member of the INLA, did not fall into any category of 'particular social group'. His membership in the INLA could not be described as an innate or unchangeable characteristic. According to La Forest J., neither could the objects of the INLA (the pursuit of independence for Northern Ireland by any means, including violence) constitute a reason for association so fundamental that renunciation would require 'an abdication of [] human dignity'. ${ }^{32}$ The Court also held that the third branch of the 'social group' was not applicable to Ward because the INLA was currently in existence. La Forest J. comments parenthetically:

It seems that this branch of the definition will only come into play when the identity of the persecutor does not coincide with that of the social group as it does in this case. For this prong to be relevant, the social group should no longer be actively affiliated; if the group has disbanded, it cannot possibly persecute. ${ }^{33}$

In addition to the three part test for membership in a social group, at least one other matter deserves special attention: The Court unequivocally repudiated the contention of the majority of the Federal Court of Appeal that the term 'particular social group' bedeemed to exclude criminals and terrorists ex ante as a matter of definition. La Forest J. notes that other general and refugee specific provisions of the Immigration Act deal with the exclusion of individuals on grounds of criminality and subversion, and further judicial narrowing of the definition is neither necessary nor appropriate. ${ }^{34}$

739.

30744.

31744 .

32745 .

3374.

34 S. 19 of the Immigration Act prohibits the admission of, inter ala, persons convicted of serious criminal offences (unless they can demonstrate that they have been rehabilitated), persons whom there are 'reasonable and probable grounds to believe' will commit a serious criminal offence or engage in organized crime, persons who have engaged or who there are reasonable grounds to believe' will engage in espionage or subversion, and persons who 'there are reasonable grounds to believe' will engage in acts of violence or 'are members of or are likely to participate in the unlawful activities of an organization that is likely to engage in such acts of violence'. The definition of refugee in s. 2 of the Act also specifically excludes persons "with respect to whom there are serious reasons for considering that' they are war crimunals, fugitives from criminal prosecution elsewhere, or have 'been guilty of acts contrary to the purposes and principles of the United Nations'. See pp. 739-43. 


\subsection{Political Opinion}

Though the Court determined that Ward was not a member of a particular social group, La Forest J. responded favourably to the argument raised by the UNHCR intervenor that Ward was persecuted by the INLA because of his political opinion, specifically his belief that the killing of innocent hostages is an unacceptable means of achieving political change. In the Court's view, this opinion was manifested through Ward facilitating the hostages' escape. Elsewhere, La Forest J. stresses that dissent alone will not suffice: 'the disagreement has to be rooted in a political conviction. This approach ... would preclude a former Mafia member, for example, from invoking it as a precedent' ${ }^{35}$ Having said that, the Court does adopt Goodwin-Gill's broad interpretation of 'political opinion' as "any opinion on any matter in which the machinery of state, government, and policy may be engaged". ${ }^{36}$

In the course of his discussion about the scope of political opinion, $\mathrm{La}$ Forest J. noted that 'the political opinion at issue need not have been expressed outright' and further, that 'the political opinion ascribed to the claimant and for which he or she fears persecution need not necessarily conform to the claimant's true beliefs.' In other words, a political opinion which is inferred from conduct or status, or which is wrongly imputed to a claimant may nevertheless form the basis for a legitimate refugee claim if the claimant is persecuted for that reason. Congruent with the Court's earlier determination about State complicity, La Forest J. affirms that 'a claimant may be seen as a threat by a group unrelated, and perhaps even opposed, to the government because of his or her political viewpoint, perceived or real'. ${ }^{37}$

\subsection{Dual Nationality}

The Court ruled that where a refugee claimant is a national of more than one country, he or she must establish the inability of each State to provide protection from the apprehended persecution as a pre-requisite to obtaining asylum in another country. ${ }^{38}$ Ward was in fact both a citizen of both the Republic of Ireland and the United Kingdom. While the original Board erroneously concluded that there was insufficient evidence to find dual citizenship, it commented that even if Ward had been a British national, 'the Board would have made a finding that the claimant's life would be in danger from the INLA if he was returned to the United Kingdom'. ${ }^{39}$

La Forest $J$. found that even if the INLA could have discovered Ward

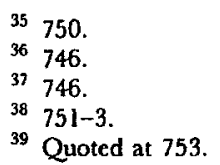


in Great Britain, the critical question was whether the British would be able to protect Ward. Consistent with his earlier remarks, La Forest J. maintained that the Board must determine this issue from an initial stance that 'Great Britain should be presumed capable of protecting its nationals' ${ }^{40}$ The Court observed, however, that an underlying premise of citizenship is the right of entry to the national territory, and it was at least arguable that the Prevention of Terrorism (Temporary Provisions) Act $1989^{41}$ derogates from that right by permitting the British Government to deny entry to the mainland of Great Britain to a national who has been 'concerned in the commission, preparation or instigation of acts of terrorism ${ }^{42}$ connected with Northern Ireland. La Forest J. countenanced the possibility that the effect of the Prevention of Terrorism Act might rebut the presumption that Ward could seek protection from Great Britain by indicating Great Britain's unwillingness to admit him.

\section{Analysis}

In an era where the gates of many nations are closing (if not slamming shut) to refugee claimants, the Ward decision is laudably progressive in many respects. It recognizes that the obligations owed by a State to its nationals in exchange for obedience encompass not only a duty to respect their human rights, but also a responsibility to protect them from having those rights violated by others. In so ruling, Ward implicitly rejects the liberal/libertarian conception of the State that sees the exercise of State power exclusively in terms of what the State does directly, and remains blind to the ways in which the State, through its inaction, facilitates the systematic abuses of some individuals by others.

The Ward decision also refuses to 'read down' the refugee definition to deny certain individuals access to refugee protection ex ante by designating them as criminals or terrorists. It adopts an expansive interpretation of 'political opinion' that implicitly acknowledges the multiple ways in which political opinion as a statement about power can manifest or be attributed. The linking of the social group definition to notions of anti-...discrimination, and section 15 of the Charter in particular, neatly disposes of at least some of the juridical constraints that have cramped the contours of the 'particular social group' catcgory. Chief among these impediments were the requirement of self-conscious affiliation and an oblique notion that the group had to be numerically 'manageable'.

Although the Court does not refer extensively to section 15 of the Canadian Charter of Rights and Freedoms, its influential role is providing a

\footnotetext{
40754.

411989 (U.K.) c.4, the current legislation replaced the Prevention of Tenonsm (Temporary Pronsions) Act 1984 (U.K.) c. 8.

${ }^{42}$ Quoted at 754.
} 
context for theinterpretation of 'particular social group' should not be underestimated. Section 15(1) provides:

Every individual is equal before and under the law and has the right to the equal protection and equal benefit of the law without discrimination and, in particular, without discrimination based on race, national or ethnic or origin, colour, religion, sex, age or mental or physical disability.

In formal terms, section 15 corresponds closely to the refugee definition: the former provides relief for victims of discrimination on certain grounds, while the latter extends protection to victims of persecution on certain grounds, some of which, such as race and religion, are explicitly common to both. The jurisprudence attaching to section 15 of the Charter appears to have informed the approach to 'particular social group' in the following ways. First, the Court found a common theme of 'anti-discrimination' linking that section and the refugee definition.$^{43}$ In the leading case of Andrews v. Law Society of British Columbia, the Supreme Court of Canada concluded that the prohibited grounds for discrimination are not confined to the enumerated heads, but extend also to characteristics that may be considered 'analogous grounds'. ${ }^{44}$ For La Forest J., 'particular social group' appears to correspond functionally to 'analogous grounds' under section 15. Andrews ruled that citizenship was an analogous ground under section $15{ }^{45}$ which in turn is roughly equivalent to the enumerated ground of 'nationality' in the refugee definition. With this pattern in mind, it becomes relatively easy to contemplate cross-fertilization in the opposite direction, and recognize sex, an enumerated head under section 15 , as a basis for a 'particular social group' under the refugee definition. The advantage of this non-discrimination approach to 'particular social group' is that it obviates the need to prove that putative members of the social group have consciously affiliated to promote some common cause.

The merits of the Ward decision can be illustrated in part by reference to the situation of women fleeing gender persecution. This phenomenon has attracted considerable media attention in Canada recently, culminating in the formulation of gender persecution guidelines by the Immigration and Refugee Board. ${ }^{46}$ Some cases involve women fleeing

43 Ward at 738

14 Andraws a Laze Socicty of Britush Columbia [1989] I SCR 143.

45 Although citizenship is related to national origin, an enumerated head under s. 15, the Court considered that it was analogous rather than identical to it.

${ }^{46}$ The IRB is an administrative agency of which one branch, the Convention Refugee De. termination Division, adjudicates inland refugee claims. The Immigration Act (Bill C-86), which came into force on 1 Feb. 1993, authorized the IRB Chair to issues Guidelines setting out the approach that IRB Members and Adjudicators are expected to follow with respect to cases involving particular sets of issues. The first to be issued by the IRB Chair, Nurjehan Mawani (on 9 Mar. 1993), were the Guidelines on Gender-Related Persecuton. See Mawani, N., 'Introduction to the Immigration and Refugee Board of Canada Guidelines on Gender-Related Persecution,' 5 ORL 240 (1993); for the text of the Guidelines, see 5 JJRL 278 (1993). 
spousal abuse in a context where the State cannot or will not protect them. The decision in Ward substantiates the argument that a woman may be persecuted for purposes of the refugee definition in such circumstances, assuming the evidence is accepted as sufficient and credible. The passages dealing with political opinion also buttress the claim that resistance to laws imposing strict controls on women's dress, conduct and opportunities may be perceived as the expression of political opinion by the State and punished accordingly. La Forest J.'s obiter remark that gender may form the basis for social group ascription eviscerates the objection that women as such are neither 'particular' nor 'unified' enough to constitute a particular social group. ${ }^{47}$ Thus, by fortuitous coincidence, the decision in Ward complements and reinforces the interpretation of the refugee definition commended by the Immigration and Refugee Board in its gender persecution guidelines, issued some four months before the judgment in Ward was released.

Like any judicial pronouncement, however, the Ward decision is reactive, dependent on the particular facts of the case, and reflects the orientation of the specific and collective judicial mindset from which it emerges. As such, it is not free from ambiguity, problematic pronouncements, and acute gaps in reasoning.

Equivocation on the point at which State inability to protect a citizen enters the refugee analysis has been noted above. ${ }^{48}$ Though the Court ultimately endorses State inability as relevant to the well-foundedness of the claimant's fear, the unarticulated corollary is that persecution subsists in the violation of a fundamental human right regardless of the identity of the perpetrator. While this may be a defensible and even salutary position to take, it departs rather strikingly from the general thrust of the international human rights regime, which identifies governments, or government-like entities, as the actors who are legally bound not to violate the fundamental human rights set out in the international instruments. Paragraph 65 of the UNHCR Handbook tacitly accepts the proposition that persecution denotes conduct for which the State is responsible, but enlarges the scope of State accountability beyond what the State does to include the consequences that flow from what it ought, but fails or is unable to do, namely, protect the national from the abusive acts of others. Ward makes the unprecedented move of dispensing altogether with the requirement that only violations for which the State may be held accountable will constitute persecution as a matter of definition. Put another way, the UNHCR Handbook posits the following equation in situations

\footnotetext{
47 Sec, for example, V. (A.P.) (Re), [1992] CRDD 318, No. U98-93227, 18 Nov 1992. citation to QuickLaw's on-line database of Convention Refugee Division Decisions.

49 See text accompanying note 15 . The confusion is exacerbated by the fact that all the scholars and cases cited with approval by La Forest J. regarding the state complicity appear to adopt the UNHCR Handbook approach. Ward, pp. 714-16.
} 
where the State is neither perpetrator nor accomplice: serious harm inflicted by private citizens plus State inaction $=$ persecution. La Forest $\mathrm{J}$. appears to veer towards the following: serious harm inflicted by anyone $=$ persecution. Here, the failure of State protection is evidence going to the well-foundedness of a claimant's fear of persecution, but does not figure in the characterization of the feared harm as persecutory.

As noted earlier, La Forest J. enumerates three alternative bases for membership in a particular social group: First, possession of an 'innate or unchangeable characteristic'; second, voluntary association with others for reasons sufficiently 'fundamental to human dignity' to preclude forcible disengagement; and third, 'former voluntary status' as a member of some collectivity, 'unalterable due to historical permanence'.

Interestingly, La Forest J. locates sexual orientation in the first category and not the second-a voluntary association for reasons fundamental to human dignity such that withdrawal cannot be demanded. Whether sexuality/same-sex preference is an inherent or a chosen orientation (or varies according to the individual) is widely debated. The purpose here is not to take issue with the correctness of the Court's classification (which is, in any case, obiter), but rather to point out that even the process of labelling sexual orientation 'innate' reveals something about the contingent nature of 'particular social groups'. Indeed, sexual orientation might have been a more useful illustration of the second category of particular social group, namely, 'voluntary association'. After all, Mr. Justice La Forest's example of 'human rights activists' as a voluntary association would more likely be resolved under the rubric of 'political opinion' than by the invocation of the residual ground of 'particular social group'.

The third category, 'former voluntary status', was adopted from the United States case Matter of Acosta. ${ }^{49}$ Regrettably, La Forest J. seems not to have grasped the scope and application of this classification. In Matter of Acosta, the Board of Immigration Appeals referred to a social group defined by 'a shared past experience such as former military leadership or land ownership'. ${ }^{50}$ The point was that past experience or status was unalterable, and as such an 'immutable' characteristic of an individual. Whether the status or group to which the claimant formerly belonged still existed was of no particular consequence. Yet, La Forest J. insists that 'former voluntary status' will only be pertinent if the group of which one is a former member is no longer 'actively affiliated'. It is unclear why this matters. If, for example, an individual is persecuted because she was once (but is no longer) a member of the 'Mothers of the Disappeared', 'I

49 Board of Immigration Appeals, Interm Decision 2986, 1 Mar. 1985.

${ }^{\text {so }}$ Quoted in Ward at 737.

5) A group of women who protested in Buenos Aires against the 'disappearance' of their children during Argentina's military dictatorship. If the claimant had been a member of the group at the time she was persecuted, then her claim would presumably fall under the 'voluntary association' classification of social group or political opinion. 
why is it relevant whether the group still exists? What if, as in Ward's case, the group was still in existence and made dissociation a capital offence? La Forest J.'s peculiar interpretation of the category labelled 'former voluntary status' hangs in mid-air with no functional connection to the anti-discrimination rationale $\mathrm{La}$ Forest $\mathrm{J}$. ascribes to the social group definition.

The Court's inclination to define 'particular social group' by linking it to notions of anti-discrimination potentially has the advantage of deemphasizing the requirement to show that the group comprises individuals who have 'united in a stable association with common purposes' ${ }^{\text {s2 }}$ Though there exist many groups, such as trade unions, that can meet this proviso, it has never been clear why it should be necessary to demonstrate selfconscious solidarity in the first place. Indeed, the ramifications of an anti-discrimination approach can assist in choosing between alternative interpretations of 'voluntary associate' as it is used in Ward to define the second and third categories of particular social groups. One possible interpretation would suggest that voluntary association requires selfconscious solidarity between the claimant and other members of the group. Another would require only that the individual assigned to the relevant social group voluntarily participate in whatever activity is used to define him or her.

In principle, an anti-discrimination approach should look at the imposed social consequences of possessing certain attributes. After all, it hardly matters to a racist whether a person of colour sees himself or herself as united with other people of colour in a stable association to achieve common purposes. As long as perpetrators of persecution treat people with a shared attribute as comprising a group by virtue of that common characteristic, whether individuals so identified would choose to see themselves as united in any meaningful sense has little impact.

The point can also be illustrated using students as a social group. Assume that a Chinese student is persecuted by police in the wake of the Tianamen Square pro-democracy, anti-government demonstrations. The student may be entirely apolitical, have taken no part in the protest, and indeed have nothing to do with fellow students outside the classroom. The police may not even care whether the student shares the views of those who participated in the demonstrations. It is enough to be a student, and for students to have instigated the demonstrations. That student cannot be said to 'voluntarily associate' with other members of the designated social group, but may be understood as being voluntarily associated with the status of student for reasons fundamental to human dignity.

From an anti-discrimination perspective, it should not matter whether

${ }^{32}$ Altomey General v. Ward, [1990] 2 FC 667 at 689, per MacGuigan J. (dissentung). 
the claimant shares the beliefs and convictions of some or all other members of the group comprised of students, as long as his or her identity qua student is given overriding normative significance and acted upon by the perpetrator of the persecution. There is here also a parallel to be drawn here with the Court's approach to political opinion. Recall Mr. Justice La Forest's point that wrongly imputed political opinions may still form the basis for a refugee claim as long as the persecutor acts in accordance with the belief about what the victim believes. Indeed, there may often be a convergence between who a claimant 'is' (or is constructed to be) and what he or she 'believes' (or is assumed to believe). It is possible to argue that Kurds in Iraq are persecuted because of their membership in a social group defined by ethnicity (who they are), and also because Kurds are assumed to hold political opinions opposed to the Iraqi government (what they believe). Of course, the more Kurds are persecuted, the more likely it will be that they oppose the Iraqi government.

Indeed, this connection between identity and political opinion may explain why counsel for Ward based his claim on inclusion in a social group, while the Court preferred the ground of political opinion. In the end, the two approaches are not very different, though it would appear that Ward's attempt to dissociate himself from the INLA was a product of his political opinion regarding INLA tactics. As La Forest J. correctly observes, the 'fact that Ward might no longer be a member [of the INLA] is merely a result of the persecution feared, not its foundation..$^{53}$

Perhaps the most troubling aspect of the Court's discussion of 'particular social group' is its inattention to the question of how to circumscribe a group in a given fact situation. The complexity of the task is illustrated by one of the lower court cases cited by La Forest J., Mayers $v$. Canada (Minister of Employment and Immigration). ${ }^{54}$ In Mayers, the claimant based her claim on years of physical and sexual abuse to herself and her children by her spouse, in circumstances where the Trinidadian police refused to intercede. On appeal, the Federal Court of Appeal found that there was evidence upon which the Convention Refugee Determination Division could find a well-founded fear of persecution based on membership in a social group comprised of 'Trinidadian women subject to wife abuse'.

The problem with the approach in Mayers is that it conflicts with the principle in refugee law that, as Hathaway unequivocally declares, '[p]ast persecution is in no sense a condition precedent to recognition as a refugee'. ${ }^{55}$ Of course, past victimization will be cogent evidence capable of substantiating a fear of future persecution as 'well founded'. By specifying the social group as 'women subject to wife abuse', however,

${ }^{53} 744$.

54 97 DLR (4th) 729 (1992).

35 Hathaway, J., The Law of Refugee Shatus (Toronto: Butterworth. 1991), 87. 
the Federal Court of Appeal effectively incorporated a requirement of past persecution into the definition of the group.

The Federal Court of Appeal's construction of the social group is also tautologous: Mayers will have a well founded fear of abuse arising out of her membership in a group consisting of Trinidadian women who are abused. While there is some merit to the contention that the antidiscrimination approach to the 'particular social group' category presupposes that members of such groups are vulnerable to victimization, it goes too far to incorporate the specific form the persecution may take into the definition of the group. Finally, the notion of employing indiscriminately all the particular attributes of a claimant's case to draw the boundaries of the social group distracts the decision-maker from isolating those factors which put the claimant at risk and runs the danger of reducing the social group down to a population of one, namely the claimant.

Thus, I would suggest that in Mayers, the Court erred in identifying the relevant group as 'Trinidadian women subject to wife abuse'. The true risk factor is one's identity as a woman. Abuse by a male partner is the persecution feared. Whether the claimant's fear of persecution is objectively 'well founded' will depend on the evidence led by the claimant, which could include evidence of past victimization and the failure of State protection. In Mayers, gender is the primary characteristic delimiting the social group. Women are persecuted by their male partners because they are women, and to encrust this basic fact under layers of qualifiers seems more likely to obscure than clarify the causal linkage between the 'particular social group' and the feared persecution.

Unfortunately, the Supreme Court of Canada's judgment in Ward misses the opportunity to articulate the parameters upon which particular social groups ought to be defined. I have contended here that the characteristics used to compose the group ought to be causally related to the persecution feared, and that the form the persecution takes should not normally be inserted into the definition of the social group. The net result of this approach will be that the correlation between membership in the social group and the 'well-foundedness' of fear of persecution will fluctuate in accordance with the level of risk faced by members of the group. This is not unusual in the context of refugee determination with respect to the enumerated bases of persecution: Not all Tamils in Sri Lanka automatically have a 'well-founded' fear of persecution by virtue of their race or or nationality, but that does not detract from the fact that a great many individual Tamils do, in fact, have such fears based on those grounds.

It is premature to speculate on the full implications of using principles drawn from anti-discrimination to guide decision-makers in giving content to 'particular social group'. It will be important for adjudicators to be 
sensitive to the cultural context in which 'particular social groups' are constructed, lest the list of 'particular social groups' be artificially limited to those which resonate in the Anglo-American repertoire of bases for discrimination. The most favourable reading of Ward would portray the Court's references to Mayers and Cheung as obiter for the purpose of delimiting social groups. Arguably, the logical implication of La Forest J.'s invocation of gender and sexual orientation as bases for social group ascription is that no further specificity need be provided. The very categories themselves connote vulnerability, in a context in which groups may be "united"not so much by common skin colour, beliefs or culture, as by the fact that those with power define them in an undifferentiated way as objects to be oppressed.

A final aspect of Ward warranting comment concerns a subtext running through the judgment. Canadian courts in general, and La Forest J. in particular, have demonstrated extraordinary deference where the conduct of the United States is at issue. ${ }^{36}$ One can only speculate on the reasons: perhaps it merely reflects the general (if tactical) Canadian subservience to United States interests, or perhaps it is because the United States is seen as sufficiently similar to Canada that any decision that impugns the behaviour of the U.S. authorities toward its citizens cuts too close to home. Of course, such motivations are unlikely to be consciously present in the minds of individual judges, yet they seem to provide a formative context within which individual cases are decided. The judgment in Ward, and cases cited therein, furnish two examples of this propensity.

After La Forest J. affirms that a State ought to be presumed capable of protecting its citizens, he cites with approval the application of this presumption in Minister of Employment and Immigration $v$. Satiacum. ${ }^{57}$ This case involved an American Indian chief who claimed refugee status in Canada on the basis that he feared for his life if incarcerated in a federal prison to which he had been sentenced. His claim was predicated on the inability of United States officials to protect him from attacks while in prison. The Immigration Appeal Board ruled in his favour, but the decision was overturned by the Federal Court of Appeal who, taking guidance from Supreme Court of Canada judgments in the area of extradition, stated as follows:

In the absence of exceptional circumstances established by the claimant, it seems to me that in a Convention refugee hearing ... Canadian tribunals have to assume a fair and independent judicial process in the foreign country. In the case of a nondemocratic State, contrary evidence might be readily forthcoming,

\footnotetext{
${ }^{56} \mathrm{Mr}$. Justice La Forest's propensity is best illustrated in various extradition cases See, for example, Kindler a Canada (Attomey-General) [1991] 2 SCR 779: extradition to face death penalty in United States does not violate right to life, liberty and security of person or right to be free from cruel and unusual punishment or treatment.

57 99 NR 171 (FCA) (1989).
} 
but in relation to a democracy like the United States contrary evidence might have to go to the extent of substantially impeaching, for example, the jury selection process in the relevant part of the country, or the independence or fairmindedness of the judiciary itself. ${ }^{58}$

In effect, the evidentiary requirements for discharging the burden in such cases are set so high that they virtually ensure no claimant from a 'democracy like the United States' will ever be able to establish his or her case. La Forest J. implicitly justifies this outcome by asserting that ' $r$ ] efugee claims were never meant to allow a claimant to seek out better protection than that from which he or she benefits already. ${ }^{59}$ In other words, it is not sufficient for the claimant to demonstrate the failure of State protection in his or her home country; the claimant could still lose if Canada could guarantee no better in similar circumstances. ${ }^{60}$

The United States makes another disturbing appearance in Ward in the Court's citation of United States Supreme Court jurisprudence. After explaining how political opinions may be manifested by conduct, in this case Ward's act of releasing the hostages, La Forest J. needlessly confuses the issue by contrasting Ward's case with a U.S. Supreme Court decision in INS v. Elias-Zacarias, ${ }^{61}$ in which Scalia J. upholds the rejection of a Guatemalan claimant who feared persecution because of his refusal to join anti-government guerillas. Scalia J. concluded that the claimant had no political motive for refusing to join (he said he feared government retaliation if he did so) and that there was no indication that the guerrillas imputed any political motivation to his refusal to join. ${ }^{62}$ La Forest $\mathrm{J}$. distinguishes Ward's situation from that of Elias-Zacarias by stating that Ward's act 'was inconsistent with any other possible motive'. ${ }^{63}$

First, the insinuation that an act must be inconsistent with any other motive in order to manifest a political opinion puts the test for inferring motive from action unrealistically high. It is more reasonable to consider whether it was likely that those whom the claimant feared would read his or her actions as politically motivated. Second, Scalia J.'s depiction of the facts before him and his understanding of what constitutes a 'political' motive is so problematic and so inextricably bound up with United States foreign policy in Central America during the relevant period, that any reference to it is ill-advised. It is dangerous and misguided to rely indiscriminately on United States jurisprudence, especially in circumstances where the law is developed and applied in a factual context

\footnotetext{
${ }^{58}$ Quoted at 725 .

59726.

${ }^{60}$ Indeed, this author doubts that Ward could have established the inability of the Irish State to protect him, had Ireland not conveniently conceded the point.

61 112 S.Ct 812 (1992); see Case Abstracts IJRL/0114 and IJRL/0115: 4 IJRL 263-6 (1992)

62729 .

${ }^{63}$ Ibid.
} 
as politically charged as was the state of affairs in Central America during the Reagan-Bush administration. In any case, Elias-Zacarias had nothing useful to add in the elucidation of principles relating to political opinion for the case before the Canadian Supreme Court. Indeed, the latter's substantive analysis of political opinion implicitly repudiates the philosophy animating the United States Supreme Court in Elias-Zacarias, and all in all it would be best to confine La Forest's use of Elias-Zacarias to the realm of obiter.

\section{Conclusion}

The Ward decision not only advances the level of sophistication in refugee jurisprudence, it also brings refugee law more explicitly into a discursive relationship with other developing loci of domestic and international human rights, particularly anti-discrimination principles. Much of the judgment can be used to facilitate a humane, reasoned approach to refugee determination, although some aspects are less salutary. The direction taken by subsequent tribunals and courts in elaborating, applying and interpreting the dicta in Ward will obviously determine its ultimate impact. Notwithstanding claims to the contrary by those who maintain that law is an apolitical enterprise, the fate of Ward is as much a question of political will as of legal determinism.

\section{Résumé}

Le récent jugement de la Cour Suprême du Canada Canada (Attomg-General) v. Ward apprécie différents aspects de la définition du réfugié au sens de la Convention. Le demandeur avait fui l'Irlande du Nord pour échapper aux représailles de l'Armée Nationale de Libération Irlandaise $(I N L A)$ à la suite de sa défection de l'organisation. Le jugement Ward renforce la position que la complicité de l'Etat n'est pas une pré-condition pour déterminer s'il y a ou non persécution en considérant que l'incapacité de la police irlandaise et britannique à protéger le demandeur contre la vengeance de l' $L N L A$ pourrait suffire à l'établissement d'une crainte fondée de persécution. Deuxièmement, la décision adopte une interprétation plutôt lange du terme 'certain groupe social' en faisant le lien avec les concepts concernant l'anti-discrimination existant dans la loi canadienne et le droit international. Incidernment, la Cour déclare que le genre et l'orientation sexuelle sont des fondements valables pour attribuer le critère de groupe social. Cependant, les faits se rapportant au cas ne permettaient pas au demandeur d'établir qu'il était persécuté pour son appartenance à un certain groupe social. D'un autre côté, la Cour était plus disposée en faveur de l'alternative relative à l'opinion politique. Dans son analyse de ce fondement, la Cour confirme que le demandeur peut être persécuté pour des raisons d'opinion politique même si cette opinion est inférée d'une conduite ou imputée de façon erronée au demandeur. Dans le cas présent, l'opposition politique de Ward contre la tactique de l'INLA pourrait être démontrée par sa conduite puisqu'il a relâché les otages qu'il avait reçu l'ordre de garder. Finalement, la décision clarifie la portée de l'exclusion pour 'double nationalité' qui peut être utilisée pour refuser une demande d'asile. Ici la Cour a trouvé que la Cour d'Appel s'était trompée en ne considérant pas que Ward était un citoyen aussi bien du Royaume-Uni que de l'Irlande, tout en mettant en garde qu'il 
était encore possible de conciure que le Royaume-Uni ne pouvait ou ne voulait pas le protéger des représailles de l'LNLA.

\section{Resumen}

El fallo de la Corte Suprema del Canada, en Canada (Attomey-General) v. Ward considera varios aspectos de la definición del refugiado según la Convención. El demandante huyó de Irlanda del norte para escapar la retaliación por parte del Ejército de Liberación Nacional Irlandés (INLA - Irish National Liberation Army) por su defección de dicha organización. La decisión en el caso Ward fortalece la noción de que la complicidad del Estado no es un prerequisito para la determinación de persecución, al encontrar que la incapacidad tanto de la policía Irlandesa o Británica para proteger al demandante de cualquier represalía del INLA bastaba para establecer un temor fundado de persecución. Además, la decisión adopta una interpretación relativamente amplia del término 'grupo social particular' al conectarlo a conceptos anti-discriminatorios en el derecho canadiense e internacional. En obiler la Corte declara que la orientación por sexo y la orientación sexual son bases permisibles para la imputación de un grupo social. A raiz de los hechos en este caso, sin embargo, el demandante no logró establecer que era perseguido por su participación en un grupo social particular. Por otra parte, la Corte tomó en cuenta la alternativa de opinión política. En su análisis de ésta base, la Corte confirma que un demandante puede sufrir persecución por motivos de opinión política aún cuando la opinión sea deducida o imputada incorrectamente al demandante. En este caso, podria inferirse la oposición política de Ward a las tácticas del INLA por su conducta al liberar rehenes que cuidaba bajo óndenes. Finalmente, la decisión clarifica la envergadura del concepto de la 'doble nacionalidad' que pudiera utilizarse para impedir una demanda de asilo. En este caso, la Corte encontró que el tribunal menor había errado al no considerar el hecho de que Ward era ciudadano tanto del Reino Unido como de Irlanda, pero advirtió que podría concluirse aún que el Reino Unido no podria o no querria protegerlo contra la retaliación del INLA. 